\title{
LOS LÍMITES DE LA AFINIDAD ENTRE LA CONCEPCIÓN DERRIDEANA DEL LENGUAJE Y LA RABÍNICA
}

\author{
MAR ROSÀS TOSAS \\ University of Chicago
}

\begin{abstract}
RESUMEN: Jacques Derrida, como otros teóricos contemporáneos, recurre repetidas veces a pensadores y categorías judíos a la hora de formular su concepción del texto y del lenguaje. A veces parece tratarse de una simple analogía; en otras ocasiones lo hace explícitamente. Esto ha dado lugar a distintos intentos de apropiación por parte del judaísmo. Susan Handelman (1982), Geoffrey H. Hartman y Sanford Budick (1986), Beth Sharon Ash (1987), Sanford L. Drob (1997; 2006), Hélène Cixous (2001), Elliot R. Wolfson (2002), Moshe Idel (2003), Bettina Bergo, Joseph Cohen y Raphael Zagury-Orly (2007) -entre otros - se han esforzado en mostrar la semejanza entre la concepción derrideana del lenguaje y la judía; algunos de ellos incluso han llegado afirmar que la primera es un simple exponente moderno de la literatura rabínica y de la Cábala. A nuestro juicio, estos intentos de apropiación son excesivos. Nuestro objetivo es, pues, explorar la analogía entre la concepción derrideana del lenguaje y la que subyace bajo la literatura rabínica y la cabalística para, en última instancia, mostrar la especificidad irreductible de la primera.

PALABRAS CLAVE: aporía, Cábala, différance, diseminación, fenómenos saturados, Harold Bloom, hors-texte, Jacques Derrida, judaísmo rabínico, lenguaje, panteísmo, significante, significado, Susan Handelman, texto.
\end{abstract}

\section{The limits of the similarity between the Derridean and the Rabbinic conception of language}

ABSTRACT: Jacques Derrida, like other contemporary theoreticians, turns several times to Jewish thinkers and categories when formulating his own understanding of text and language. Sometimes it seems like just an analogy, but other times he does it explicitly. This has given rise to several attempts of appropriation on behalf of Judaism. Susan Handelman (1982), Geoffrey H. Hartman and Sanford Budick (1986), Beth Sharon Ash (1987), Sanford L. Drob (1997; 2006), Hélène Cixous (2001), Elliot R. Wolfson (2002), Moshe Idel (2003), Bettina Bergo, Joseph Cohen and Raphael Zagury-Orly (2007) - among others - have tried to show the similarity between the Derridean and Jewish concepts of language; some of them even go so far as to claim that the first is a mere modern representation of the Rabbinic Literature and the Kabbalah. In our opinion, these attempts of appropriation are excessive. Thus, our goal is to explore the analogy between the Derridean understanding of language and the Jewish counterpart at stake in Rabbinic and Kabbalistic literature, in order to show, ultimately, the irreducible specificity of the former.

KEY WORDS: aporia, différance, dissemination, Harold Bloom, hors-texte, Jacques Derrida, Kabbalah, language, pantheism, Rabbinic Judaism, saturated phenomena, signified, signifier, Susan Handelman, text.

\section{INTRODUCCIÓN}

Una serie de pensadores y teóricos literarios contemporáneos han empleado categorías del pensamiento judío para oponerse a algunos conceptos fundamentales del pensamiento occidental de raíz greco-cristiana. ${ }^{1}$ Susan A. Handelman ha estudiado

1 En el capítulo ocho, Handelman (1982) sostiene que una serie de críticos - John Crowe Ransom, Robert Penn Warren y Cleanth Brooks, así como los teóricos que les siguieron- persiguieron el sueño 
magistralmente este fenómeno. En su libro The Slayers of Moses: The Emergence of Rabbinic Interpretation in Modern Literary Theory (1982) compara el modelo estructural de la interpretación del judaísmo rabínico con las teorías del significado de algunos teóricos contemporáneos, y se esfuerza en mostrar que la falta de atención ${ }^{2}$ que la cultura occidental manifiesta hacia la tradición rabínica es un grave error, puesto que, según Handelman, las estructuras y patrones del judaísmo rabínico son visibles en pensadores y teóricos literarios occidentales contemporáneos. Handelman tiene in mente a Barthes, Bloom, Derrida, Freud y Lacan, así como a la escuela de Yale.

A nuestro juicio, de todos ellos es en Jacques Derrida (1930-2004) donde la tradición judía — como veremos, especialmente la rabínica pero también determinadas ideas propias de la Cábala - ha dejado su impronta de forma más radical. Jacques Derrida, de origen judío, se introdujo en los círculos de filosofía continental de Francia de mediados de siglo veinte, donde imperaban versiones más o menos secularizadas de los conceptos centrales de la tradición greco-cristiana occidental, y, desde dentro, criticó los postulados de esta «metafísica de la presencia». Sin duda alguna, el pensamiento derrideano, al criticar la metafísica de la presencia occidental, recurrió numerosas veces a distintos pensadores judíos, ${ }^{3}$ y el propio Derrida señaló la afinidad de su concepción del texto con algunas categorías pertenecientes a la tradición judía. ${ }^{4}$ Incluso llegó a admitir, en Circonfession (1991), "ser el último de los judíos», 5 situándose, así, en un espacio de bisagra entre lo judío y lo no judío.

Esta afinidad entre la visión derrideana del lenguaje con las categorías centrales del judaísmo - especialmente con el tipo de exégesis textual propia de la literatura rabínica- ha sido subrayada y explorada por un amplio número de estudiosos, ${ }^{6}$ no solo por Handelman. A veces se trata de una deuda implícita, pero Derrida a menudo recurre explícitamente a nociones propias de la concepción judía del lenguaje. De hecho, esta deuda no se deja sentir exclusivamente en los textos derrideanos de índole eminentemente

helénico de la lógica, el orden y la lucidez. En cambio, otros teóricos —cuyas propuestas, según Handelman, presentan claras afinidades con la concepción rabínica del texto- consideran que la textualidad está impregnada de una serie de contradicciones lógicas que imposibilitan esa empresa. Véase Questions au judaïsme de Weber (1994), y la obra colectiva editada por Hartman y Budick que lleva por título Midrash and Literature (1986).

2 Que Handelman atribuye principalmente a tres motivos: la estigmatización que hizo la Iglesia de la interpretación rabínica, la inaccesibilidad de las fuentes judías para quien no conocía la lengua hebrea, y la exclusión (relativa) de los judíos de la vida intelectual de Europa hasta la Ilustración.

3 A veces de forma directa —Emmanuel Lévinas (Derrida 1997); Paul Célan (Derrida 1986)...—; otras veces a través de autores que, a su vez, habían absorbido parte del legado judío. Véase el interesante artículo de Greenstein, «Derrida and the Diaspora» (1986). Su autor sostiene que Derrida critica la modernidad sirviéndose de conceptos acuñados por autores occidentales de tradición judía, como es el caso de Marx y Freud.

4 También insinuó que ciertos elementos de la tradición judía mantienen un claro parecido con propuestas que la ortodoxia no puede clasificar dentro de los límites de las religiones del Libro. Por ejemplo, en La dissémination (1972), Derrida señala que la Cábala, en su textualidad y plurivocalidad, evidencia un tipo de ateísmo.

5 Hay que tener en cuenta que Derrida juega con el doble sentido del adjetivo último: no tiene solamente una connotación temporal, sino también peyorativa; «el último» puede significar «el peor», es decir, el que vive y piensa de una manera menos judía.

6 Véase Judeities. Questions for Jacques Derrida (2007), editado por Bergo, Cohen y Zagury-Orly, para un estudio de la herencia judía en Derrida. Véase también Hélène Cixous (2001); Harold Bloom (1979); Sanford L. Drob (1997; 2006); Susan Handelman (1982); Geoffrey H. Hartman y Sanford Budick (1986); Moshe Idel (1986; 2003); Beth Sharon Ash (1987); Elliot R. Wolfson (2002). 
lingüística, sino también en los que versan sobre cuestiones éticas, ${ }^{7}$ políticas, ${ }^{8}$ teológicas y religiosas, así que no es de extrañar que el pensamiento derrideano haya dado lugar a distintos intentos de apropiación por parte del judaísmo. ${ }^{9}$

Sin embargo, a nuestro juicio, estos intentos de apropiación de las tesis lingüísticas de Derrida son excesivos. Es por ello que, en última instancia, nuestro propósito es discernir y exponer los elementos originales del enfoque derrideano sobre el lenguaje. Para ello, nos parece indispensable primero exponer la concepción rabínica del texto (Sección I). Luego, explorar cuáles de sus elementos son también constitutivos de la teoría literaria contemporánea, particularmente del pensamiento de Harold Bloom, en quien dicha deuda se hace especialmente explícita (sección II). Finalmente, en la sección III, nos centraremos en la concepción derrideana del lenguaje para, en primer lugar, mostrar cómo la afinidad de su pensamiento con la tradición rabínica es aun más radical que en Bloom y en otros teóricos literarios contemporáneos, y, en segundo lugar, para mostrar que, a pesar de eso — y a pesar de Drob (1997; 2006) e Idel (2003)_, existen al menos tres motivos por los cuales su visión del texto resulta en última instancia irreducible a la concepción rabínica del texto.

Es preciso subrayar que, aunque en el presente texto nos centramos en el ámbito lingüístico, la argumentación que desarrollamos puede extrapolarse sin dificultad a las reflexiones éticas, políticas y religiosas de Derrida, dado que la obra derrideana, a pesar de haber cambiado el foco de atención en distintas ocasiones, es de una extraordinaria coherencia y continuidad. ${ }^{10}$

\section{La CONCEPCión RABÍNICA DEL LENGUAJE}

El judaísmo rabínico se originó en tiempos del segundo Templo (s. IV aC o III aC), y se extendió y consolidó entre la destrucción del segundo Templo (70dC) y la redacción del Talmud de Babilonia hacia el siglo vi dC. Se trata de un tipo de exégesis bíblica en la que tiene un papel fundamental la ley oral: se considera que Yavé dio la ley a Moisés en el Monte Sinaí - por lo que dicha ley tiene una autoridad divina- y que a partir de entonces se transmitió oralmente de generación en generación hasta que quedó recogida en el Talmud. ${ }^{11}$ En el judaísmo rabínico, pues, se considera tan vinculante la ley oral como la Torá. Es más, se considera que dicha ley oral ilumina la Torá, permite comprenderla mejor. El judaísmo rabínico es, pues, esencialmente interpretativo. Y dicha interpretación no puede detenerse porque, aunque la ley fue otorgada a Moisés en el Sinaí, la revelación es continua.

7 Por ejemplo, la hospitalidad o acogida incondicional del Otro, que constituye una categoría central de la obra de Derrida, es una categoría fuertemente enraizada en la tradición judía, como pone de manifiesto Francesc Torralba en «No olvidéis la hospitalidad» (Heb 13,2). Una exploración teológica (2004). Véase De l'hospitalité (Derrida; Dufourmantelle 1997) y «Hostipitality» (Derrida 2002).

8 Por ejemplo, en la expresión «mesianicidad sin mesianismo», que Derrida acuña en Spectres de Marx (1993) y vuelve a tematizar en «Foi et savoir» (1996). También, en su digresión sobre el término schibboleth (Derrida 1986).

9 Como botón de muestra, véase Idel (2003) y Sanford L. Drob (1997; 2006). Drob (2006) llega a afirmar que Derrida es un representante moderno de la Cábala luriánica. Véanse los diecinueve paralelismos que Drob, en su texto «Jacques Derrida and the Kabbalah», dice que detecta entre el pensamiento de Derrida y el de Luria.

10 Véase Rosàs Tosas (2008).

11 Compuesto por la Mishná y la Guemará. 
El proceso de interpretación, pues, no se detuvo con la redacción del Talmud. Este no se concibió como una fijación definitiva de la ley oral; le siguieron muchos comentarios. Podría decirse que se forjaron talmuds sobre el Talmud. ${ }^{12}$

La larga historia de la producción textual del judaísmo rabínico, así como su carácter extraordinariamente prolífico, dificultan sumamente, si no es que imposibilitan, la posibilidad de proporcionar una definición completa de la concepción del lenguaje y del texto que subyace en estos textos y comentarios. La literatura rabínica nunca hace una abstracción de las normas que gobiernan su relación con el texto; dichas normas no se hacen explícitas, e incluso resulta imposible afirmar que existan unas normas estables que funcionan del mismo modo en todos los textos y épocas. Sin embargo, como veremos en lo que sigue, el motivo mismo que ha inducido e induce a la elaboración de más y más textos —a saber, comentarios sobre los textos sagrados - tiene que ver precisamente con una visión común del lenguaje, de la escritura y del texto sagrado. Es a esta visión a lo que nos referiremos.

Como pone de relieve el minucioso y rico trabajo de Susan A. Handelman (1982), la visión rabínica del texto se basa en la unidad fundamental entre el texto sagrado y la realidad. La literatura rabínica subraya esa idea en múltiples ocasiones. Por ejemplo, el versículo "Estúdiala y estúdiala porque todo está en ella» ${ }^{13}$ (Avot 5: 21) ${ }^{14}$, atribuido a Ben Bag Bag, sugiere esta idea, como también la sugiere lo que según la literatura rabínica Ismael recomendó al rabino Meir para que fuese un buen escriba de la Torá: "porque si te dejas una sola letra o escribes una sola letra de más, serás como si destruyeses el mundo entero» ${ }^{15}$ (Eruv. 13a). ${ }^{16}$

Esta concepción del texto, en la que parece que se da una identificación entre la realidad y el texto, difiere claramente de la cristiana que, enraizada en el pensamiento de Platón y Aristóteles — para quienes la verdad se halla más allá del lenguaje_-, se basa en la idea de que el texto sagrado es un medio que proporciona información de una realidad exterior al texto y superior a él. Es en el diálogo titulado Crátilo donde Platón desarrolla la idea a la que nos referimos. En él tiene lugar un debate entre Sócrates, que sostiene que hay palabras cuya sonoridad es más adecuada para referirse a ciertas cosas — de modo que el lenguaje tiene un origen natural—, y Hermógenes, que defiende que el lenguaje es mera convención. Finalmente, Crátilo — que representa el enfoque hasta aquel momento más clásico- propone un tercer modo de relacionar las palabras con las cosas. Según él, los dioses han proporcionado las palabras a los hombres, de modo que necesariamente se corresponden con las cosas. Sin embargo, Sócrates no puede estar de acuerdo, puesto que según él las palabras no logran expresar a la perfección las cosas a las cuales se refieren. He aquí la naturaleza inferior de las palabras respecto de la realidad a la que se refieren; las palabras pertenecen al reino de la imperfección, mientras que las cosas pertenecen al reino de las formas inmutables y perfectas. Platón pone estas ideas en boca de Sócrates, pero también habría que atribuirlas al propio Platón.

Aunque Aristóteles ${ }^{17}$ optó por un modelo convencionalista, compartió con Platón —y con la tradición greco-cristiana que inspiró- la idea de que las palabras no contienen o incluyen la realidad, sino que se refieren a ella.

12 Para una historia de la gestación del Talmud, véase el segundo capítulo del libro de Handelman.

13 (Trad. de la A.).

14 Avot es un tratado sobre las enseñanzas éticas de algunos rabinos que forma parte del cuarto orden de la Mishná, (el Neziqín), una recopilación de las leyes orales judías que se fue forjando durante los dos primeros siglos de nuestra era. Las citas del Talmud proceden de la edición de Steinsaltz.

15 (Trad. de la A.).

16 Eruvin se halla en el segundo orden de la Mishná, el Moed.

17 Véase el quinto libro de la Metafísica de Aristóteles. 
En esta misma línea, San Agustín, en su reflexión fundacional sobre los signos, afirma que solamente son importantes por lo que significan más allá de ellos, ${ }^{18}$ puesto que son meros intermediarios (De magistro: 53). También en De doctrina christiana da por descontado que las palabras o los signos son meros medios que sirven para llegar a otra cosa. Escribe: «el signo, en efecto, es la cosa que, además de la especie [o imagen, o representación] que introduce en los sentidos, hace llegar al pensamiento de otra cosa distinta». ${ }^{19}$ Así pues, los signos no tienen especial valor en sí mismos, sino solo en tanto que medios que deben permitir la comunión con la presencia. La verdad se encuentra más allá de los signos. Para San Agustín, la adhesión de los judíos a los signos no es sino idolatría. El lenguaje tiene que ser superado.

Puede parecer que esta última afirmación esté en contradicción directa con el hecho de que para el cristianismo Jesucristo constituya la Palabra encarnada. Sin duda, el cristianismo otorga una importancia crucial al Logos o Palabra. Sin embargo, en este punto es pertinente sacar a colación una observación de Handelman que ilustra la idea del papel siempre secundario que desempeñan en el cristianismo el lenguaje, el libro, los signos y la palabra: la Encarnación no celebra propiamente la palabra — como suele decirse-, sino la transformación del orden lingüístico al reino material (Handelman 1982: 4). Para el cristianismo, Jesucristo constituye el referente último de los textos judíos escritos hasta el momento; Jesucristo les otorga sentido y acaba con la necesidad de interpretar y escribir.

En cambio, a diferencia de la tradición greco-cristiana, para el judaísmo rabínico no hay nada más sagrado ni más real que el texto. El texto, Dios y la realidad son, sustancialmente, lo mismo. ${ }^{20}$ Fijémonos en esta tesis. Según esta visión del texto y del mundo, la realidad es el resultado de todas las combinaciones posibles de las veintidós letras del alfabeto hebreo, y este alefato, a su vez, está comprendido en la impronunciable palabra $Y H W H$. Dicho de otro modo, la realidad es eminentemente lingüística. La materialidad del ser es textual. E incluso el nombre de Dios, a su vez, está atravesado por el lenguaje..1

Así pues, el libro sagrado, a saber, la Torá, no es un medio para conocer a Dios y el mundo, ni tampoco puede ser considerada un producto del mundo. La Torá precede al mundo ${ }^{22}$ (Shabbat 88b). ${ }^{23}$ Según el inicio del Midrash Rabbah —un libro que contiene la antigua interpretación rabínica del libro del Génesis- Dios consultó la Torá para diseñar el mundo, del mismo modo que un arquitecto consulta planos para construir un palacio. En consecuencia, la Torá contiene la esencia del mundo o, para ser más precisos, su estructura subyacente. Si se descifra el texto puede comprenderse el mundo. Ahora bien, por más esfuerzo que se empeñe en descifrar el texto sagrado no se logrará una interpretación definitiva y cerrada ni de él ni del mundo. Si la realidad es texto —es decir, significante-, es obvio que la interpretación no puede dar con su sentido o significado último; los significados son necesariamente extratextuales, pero la visión

18 Para un exhaustivo análisis de esta tesis y sus implicaciones, véase «Signo y lenguaje en San Agustín» (Maurice Beuchot 1986). El punto de partida de Beuchot es precisamente que, para Agustín, «[1] as palabras o signos lingüísticos, y los signos en general, son únicamente medios para llegar a las cosas significadas, que son los fines de éstos. [...] O sea que los signos palidecen para dejar brillar a las cosas a las que remiten, porque todo lo que es en vistas a otra cosa necesariamente está supeditado a ella y vale menos que ella». (Beuchot 1986: 21).

19 Pasaje de De doctrina christiana de San Agustín citado en Beuchot (1986).

20 De ahí que el judaísmo difícilmente pueda escapar al panteísmo.

21 Como sostiene Wolosky, el nombre de Dios es polisémico; está roto, escindido (Wolosky 1998:

270) porque la diferenciación del lenguaje penetra la propia divinidad (Wolosky 1998: 274).

22 La Torá, pues, no constituye algo material ubicado en el tiempo; o no solamente.

23 Shabbat se halla en el segundo orden de la Mishná, el Moed. 
rabínica del texto excluye una realidad ajena al texto. Esto no significa que el texto sagrado lo pueda significar todo. Más bien habría que decir, con Roitman, que «[t]odo está determinado y sin embargo todo está abierto » ${ }^{24}$ (Roitman 1986: 160). Nunca se da una interpretación unívoca de un pasaje ni de un vocablo. En la literatura rabínica se hallan numerosos ejemplos que sostienen esta idea. Uno de sus fundamentos es el salmo 62, en el que hay un versículo que reza así: «Dios ha hablado una vez; dos veces, lo he oído» $($ Sal 62,12$) .{ }^{25}$ La exégesis rabínica también se apoya en el siguiente pasaje, a partir de cual se dedujo que del mismo modo que un martillo rompe las rocas en muchas piezas, cada verso puede «estallar» en muchos significados distintos: «¿No es así mi palabra, como el fuego, y como un martillo golpea la peña?» (Jr 23, 29).

En definitiva, para la tradición rabínica, la interpretación no puede concluir jamás. El judío vive en una desposesión permanente, en un exilio perpetuo.

Una de las consecuencias de esta concepción del texto y del mundo es que el comentario del texto no es una actividad secundaria, sino que, en realidad, tiene la misma importancia que el texto. El texto - tanto la realidad como el texto sagrado- está formado por el entramado de sucesivos comentarios e interpretaciones, de modo que el texto y su comentario se copertenecen. En última instancia, pues, en la tradición judía —a diferencia de la cristiana- no puede distinguirse entre el texto y su comentario.

El sentido de los términos que la lengua griega y la hebrea emplean respectivamente para designar palabra sintetiza estas diferencias entre las concepciones greco-cristiana y judía del texto: mientras que el término griego onoma significa "palabra», el término hebreo davar significa, simultáneamente, "palabra» y «cosa». El doble sentido de davar pone de manifiesto que, para la tradición rabínica, el lenguaje no es un instrumento que designa la realidad, sino que ya es la realidad misma. En pocas palabras: el lenguaje constituye la realidad.

En consecuencia, no puede interpretarse la realidad desde fuera del lenguaje. El onoma griego apunta más allá del texto, mientras que el davar judío se dirige hacia dentro, hacia el texto mismo y su red de interrelaciones (Handelman 1982: 31). Y esto, a su vez, conlleva la mencionada imposibilidad de lograr una interpretación definitiva de la realidad/texto.

\section{LA SUPERVIVENCIA DE LA VISIÓN RABÍNICA DEL TEXTO EN LA TEORÍA LITERARIA CONTEMPORÁNEA}

Buena parte de la teoría literaria contemporánea se nutre, aunque sea de manera inconsciente e indirecta, ${ }^{26}$ de esta idea. El caso de Harold Bloom es particularmente ilustrativo en ese aspecto, puesto que en un determinado momento de su trayectoria dice haberse dado cuenta de que su sistema de interpretación textual guarda un asombroso parecido con determinadas ideas propias del judaísmo. ${ }^{27}$

Antes de ese momento, Bloom sostiene que la escritura y la lectura son intentos de rebelarnos contra el precursor, es decir, contra la máxima autoridad que ha permitido

24 (Trad. de la A.).

25 Las citas de la Biblia proceden de la Biblia de Jerusalén.

26 Y, probablemente, incluso a veces se trate de un paralelismo casual. Mostrar los canales de influencia — sin duda múltiples y complejos- entre la tradición rabínica y la teoría literaria contemporánea supera el objetivo de este trabajo. Pretendemos mostrar el paralelismo entre ambas visiones del texto, pero no dedicamos este trabajo a justificar los posibles motivos de esta analogía.

27 Véase La Cábala y la crítica (1975b). 
que nosotros existamos en tanto que escritores y lectores. En La angustia de las influencias (1973) explica que escribir y leer consiste en intentar deshacerse de las autoridades para hacerse el propio espacio. Este esfuerzo y la conciencia de que los fantasmas de estos precursores nos acechan generan angustia. El espacio propio es, realmente, reducido. La rebelión total contra los que nos han precedido está condenada al fracaso. No obstante, la tarea de todo nuevo escritor es importante: toda nueva creación literaria es una nueva lectura que sirve para comprender mejor los textos anteriores, puesto que hace aflorar aspectos suyos que, hasta entonces, estaban solo latentes; y, a su vez, toda nueva escritura, como toda nueva lectura, añade algo. En La angustia de las influencias (1973), Bloom propone seis fases, ${ }^{28}$ que él bautiza como "proporciones de revisión» [revisionary ratios], por las que pasa la relación de todo escritor y todo lector con los textos que le preceden. Su tesis principal es que ningún texto agota su potencial en sí mismo, sino que debe aguardar a ser leído y releído en estas distintas fases. Toda lectura y toda escritura son revisión. Bloom concluye, en consonancia con esta idea, que solamente hay «malas lecturas» ${ }^{29}$ y no textos ni poemas estáticos esperando a ser descifrados. Se desmarca, pues, de una serie de teóricos literarios anteriores a él que confiaban en la posibilidad de captar lo «esencial» del texto. ${ }^{30}$

Dos años más tarde, Bloom publicó La Cábala y la crítica (1975). Es en este texto donde dice haber descubierto que su teoría sobre la influencia funciona prácticamente igual que la Cábala, especialmente que la de Cordovero y la de Luria. Para nuestro propósito es importante tener in mente que, como se esforzó en demostrar Scholem, las categorías que articulan la Cábala no difieren en esencia de la literatura rabínica. ${ }^{31}$ Moshé ben Ya'acob Cordovero fue, junto con Isaac Luria, el cabalista más importante del núcleo cabalístico que en el siglo Xvi, tras la expulsión de los judíos de España, se creó en Safed, Palestina. Opuesto en muchos aspectos a Luria —en su sistematicidad, por ejemplo, como explicó Scholem en la séptima conferencia que compone Las grandes tendencias de la mística judía (1941) - ofreció una nueva interpretación y descripción del legado más antiguo de la Cábala, especialmente del Zohar. Es conocido, sobre todo, por su descripción del funcionamiento de las sefirot.

A lo largo de La Cábala y la crítica, Bloom prueba que tanto el contenido como el método de la Cábala presentan paralelismos evidentes con su teoría de la influencia. Según la Cábala de Cordovero, el mundo ha emanado de Dios, es decir, del Ein-Sof o sin-término. El mundo emana progresivamente de Dios o, lo que es lo mismo, Dios se va manifestando a través de distintas fases, llamadas sefirot: ${ }^{32}$ Keter, Hokmah («sabiduría»), Binah («inteligencia»), Gedullah («grandeza») o Hesed («amor»), Gevurah («poder») o Din («juicio» o «rigor»), Tiferet («belleza») o Rahamin («miseria»), Nezah

28 Clinamen, Tessera, Kenosis, Daemonization, Ascesis y Apophrades.

29 Véase Map of Misreading (Bloom 1975a).

30 Véase la nota 1.

31 Como mostró Scholem (1941), la Cábala es la mística judía —estrechamente vinculada con la tradición rabínica - que comienza alrededor del año 1200 en la Provenza. Literalmente, cábala significa «recepción» y «tradición». De hecho, cabría definirla como «recepción de la tradición». Según Scholem: «en ella, una tradición originariamente judeo-gnóstica, que se ha elaborado por completo en un ambiente religioso y en la que no juegan ningún papel consideraciones propiamente filosóficas, se encuentra con el neoplatonismo, es penetrada por él, de él se defiende y en todo caso no es posible concebir el encuentro entre esas dos tradiciones sin vivísimo debate» (Scholem 1970: 17). Scholem también se esfuerza por mostrar que la Cábala no difiere en esencia respecto del pensamiento rabínico.

32 Algunos cabalistas entendían las sefirot como herramientas o instrumentos a través de los que Dios se manifestaba. Sin embargo, también hubo quien consideró que las sefirot no eran meras herramientas al servicio de la manifestación de la divinidad, sino que participaban de esta divinidad. 
(«aguante duradero»), Hod («majestad»), Yesod («fundación») y Malkhot («reino»). Cordovero explicó cómo cada una de estas sefirot se relaciona con la sefirá precursora: la sefirá nueva no es la negación de su precursora, ni tampoco su total realización; ella permite que se manifieste algo que, en la sefirá anterior, aún estaba oculto; y, a la vez, intenta desmarcarse de la sefirá anterior. Cordovero explica detalladamente cómo cada sefirá se relaciona con las anteriores y las siguientes. Según él, esta relación está regulada por seis behinot. ${ }^{33}$

Bloom dice haber descubierto que su teoría de la influencia funciona igual que este modelo cabalístico: cada texto o cada poema es como una sefirá que se relaciona con el texto o poema anterior mediante las seis behinot que, en el modelo de Bloom, tienen su análogo en las seis fases que todo nuevo texto debe pasar en su constituirse frente a su precursor. En palabras del propio Bloom: "Cordovero proporciona el modelo de mis seis "proporciones de revisión" con sus seis behinot o aspectos de cada sefirah" (Bloom 1975b: 62).

La hipótesis de Bloom es, pues, que los cabalistas, para explicar la creación del mundo a partir de la progresiva manifestación de Dios, desarrollaron lo que él llama una «psicología del retardo» (Ibíd.: 33-34) que funciona de manera análoga a su teoría de la influencia: ningún texto, como ninguna sefirá, manifiesta algo en su totalidad; la completitud está en otro sitio; el nacimiento de cada nueva sefirá y de cada nuevo texto aspira a acercarse más a esta completitud. ${ }^{34}$

Bloom considera que también la Cábala de Isaac Luria es una teoría de la influencia. Luria (Safed, Palestina, s. Xvi) propuso la siguiente manera de leer el comienzo de la historia humana y cósmica: en el principio, Dios se contrajo para hacer sitio para la creación. La originalidad de esta aproximación a la creación es que el mundo no surge de la expansión de Dios, sino de su contracción. Esta retracción, que se conoce como tsimtsum, debe entenderse, pues, como una peculiar forma de enfrentarse a la compleja cuestión sobre la creación del mundo: si el Ein-Sof lo es todo, ¿cómo puede haber algo fuera de él? Así pues, para este cabalista, la creación del mundo no es un acto de afirmación y concentración de poder, sino una contracción para hacer espacio (tsimtsum); ${ }^{35}$

33 Bloom describe las behinot como «imágenes poéticas que pueden considerarse como tropos maestros o como mecanismos decisivos de defensa» (Bloom 1975b: 70). Su función es regular el paso de una sefirá a la siguiente. Por ejemplo, la primera behiná de toda sefirá consiste en que el nuevo poema ya está presente en el poema precursor, aunque de manera oculta (Ibíd.: 66). La segunda behiná permite avanzar un poco más: el «poema oculto en el poema anterior emerge de su ocultamiento. Pero sigue estando en el poema anterior, lo cual quiere decir que nos hemos desplazado de las imágenes dialécticas de la presencia y de la ausencia hacia las imágenes de la sinécdoque que se refieren a la parte y el todo» (Ibíd.: 67). La tercera behiná funciona como una metonimia y la cuarta, a su vez, «es el aspecto que permitió a su precursora ser lo bastante fuerte como para hacer emanar fuera de sí a la sefirah posterior» (Ibíd.: 69). La quinta «es el poder propio que tiene la sefirah o poema para hacer emanar hacia afuera las sefirot que lleva ocultas dentro de sí, lo cual significa que como tropo la quinta behinah es una metáfora, una imagen dualística que contrapone el adentro y el afuera» (Ibíd.: 70). Finalmente, la sexta behiná «es una reversión metaléptica de la quinta, ya que por este aspecto final la sefirah siguiente, próxima en la serie, es emanada hacia el lugar que le corresponde, tras lo cual el ciclo completo comienza nuevamente con la primera behinah de la sefirah siguiente» (Ibíd.: 70).

${ }_{34}$ Para una lectura psicológica del proceso de emanación descrito por los cabalistas, véase Drob (1997), «The Sefirot: Kabbalistic Archetypes of Mind and Creation». De hecho, el propio Bloom recurre explícitamente al psicoanálisis para explicar la relación que se establece entre las diferentes «proporciones de revisión".

${ }_{35}$ Para una detallada explicación del proceso de creación según Luria (que se inicia con el fenómeno del tsimtsum, pero que es seguido de otros dos fenómenos igual de determinantes para la constitución del mundo —la shevirá y el tiqqún), véase Scholem (1941; 1971) e Idel (1992: 91-92). 
según Bloom, de forma análoga el poema viejo se contrae para dejar lugar a la creación del poema nuevo.

Es importante hacer notar que Bloom no se centra en las cuestiones lingüísticas y textuales tratadas explícitamente en la Cábala, sino en dos cosmogonías - la de Cordovero y la de Luria-. Es cierto que tanto Cordovero como Luria están llevando a cabo un ejercicio textual - están interpretando el mito judío de la creación contenido en la Torá-, pero, sin embargo, lo que llama la atención de Bloom no es lo que en sus textos hay de interpretación textual, sino la manera cómo, yendo mucho más allá de lo insinuado por el Génesis, imaginan la creación y organización del mundo. ¿Por qué motivo Bloom se atreve sin problema a aplicar las fases por las que pasa la creación del mundo —algo perteneciente al campo de la cosmogonía y la ontología- a las fases por las que pasa la interpretación de un texto - algo eminentemente epistemológico?

A pesar de no hacerla explícita en La Cábala y la crítica, la siguiente idea está latente en toda esta obra de Bloom: porque para los cabalistas -así como para la tradición rabínica, tal y como hemos mostrado- la realidad es eminentemente lingüística. Dicho de otro modo, porque, según ellos, no existe una distinción nítida entre la ontología y la epistemología. Dichos cabalistas entendían el mundo como texto; para ellos, comprender la creación equivalía a comprender un texto. En la medida en que comprender el mundo era un ejercicio interpretativo, constituía también una tarea textual.

Bloom concluye que tanto su teoría de la influencia como la Cábala giran alrededor de la idea de que la lectura correcta es imposible, porque todo texto recibido es, ya, interpretación. Solo hay, pues, malas lecturas. La distorsión nutre a la tradición; es, pues, creadora. El texto supuestamente original solamente vive en perpetuas mutaciones: para Bloom, no hay textos estables, sino solo interpretación; de manera análoga, para la Cábala, la única revelación posible es la interpretación. No hay que trascender el texto, sino permanecer en él. Nunca se logrará una interpretación completa, unívoca y definitiva del texto. ${ }^{36}$

Ahora bien, la analogía de la teoría literaria contemporánea con la tradición judía no se reduce a Bloom. Ni es el único teórico en el que se hallan elementos propios de la concepción rabínica del texto, ni es el único que reconoce esa afinidad —aunque sí fue el primero en exponer y tematizar dicha afinidad-. Sin embargo, sí es cierto que los paralelismos que se dan entre su concepción del texto y la rabínica —que luego él mismo percibe y explora-incluyen todos los puntos y cuestiones característicos de la tradición rabínica y de la cabalista que se hallan en otros teóricos contemporáneos.

A grandes rasgos, puede decirse que la teoría literaria contemporánea comparte con el judaísmo rabínico los siguientes puntos, íntimamente relacionados entre sí: la imposibilidad de dar con una interpretación definitiva y cerrada de un texto; la inexistencia

36 Bloom amplió su teoría sobre la angustia de las influencias en Los vasos rotos (1982). En este libro, con el fin de proporcionar paradigmas sólidos para superar las lecturas normativas o débiles de la poesía romántica, se ayudó de categorías procedentes del psicoanálisis para tratar de demostrar la naturaleza intertextual de la poesía romántica y, por extensión, de toda poesía: un poema nunca es completo, sino que niega el anterior mientras que, simultáneamente, le ayuda a desplegarse más ampliamente y surge de él. Ningún escritor, como tampoco ningún lector, puede estar en una posición objetiva o neutra. En palabras del propio Bloom:

\footnotetext{
Ningún lector, no importa cuán profesional, humilde, pío, desinteresado, «objetivo», modesto o amigable que sea, puede describir su relación con un texto anterior sin adoptar una posición no menos tropológica que la ocupada por el texto mismo [...]. Cuando Paul de Man me dice que una posición epistemológica respecto a un texto literario goza de un privilegio necesariamente mayor que cualquier posición estética y moral, lo único que me queda es sonreír gozosamente y replicar que tal posición no es ni más ni menos literaria (Bloom 1982: 43).
} 
de un metalenguaje; el carácter textual de la realidad; la idea de que la tarea del comentarista/ crítico no es descifrar una verdad atemporal e inequívoca del texto, sino convertirlo en una fuente incesante de sentido; la imposibilidad de discernir entre el texto y su comentario; la bidireccionalidad de las influencias textuales (no únicamente un texto antiguo influye un texto nuevo, sino que un texto nuevo también influye el sentido de uno antiguo).

Todas ellos constituyen asunciones características de los teóricos literarios contemporáneos que se inscriben dentro de la línea abierta en los años setenta por la llamada escuela de Yale. Algunos teóricos se centran más en una de estas ideas. Para proporcionar solo un ejemplo: Barthes, en «From Work to Text» (1979: 81), advierte y analiza la idea de que el discurso sobre el texto siempre es texto, de modo que no puede darse con una exposición metalingüística del texto. En última instancia, el análisis del proceso de interpretación no puede separarse del proceso mismo de interpretación, puesto que ambos están regidos por las mismas normas.

Indudablemente, la propuesta de Derrida comparte todos los puntos mencionados tanto con la teoría literaria como con la tradición rabínica. Pero, a nuestro juicio, su afinidad con la visión rabínica del texto es más radical.

\section{Lenguaje y Diferimiento EN JAcQues DerRidA}

En lo que sigue, explicaremos las tesis matriciales del pensamiento de Derrida, luego señalaremos su afinidad con la tradición rabínica, para finalmente indicar y explorar los tres elementos que, a nuestro juicio, son exclusivos de la propuesta derrideana, lo cual imposibilita reducirla en última instancia a la concepción rabínica del lenguaje.

Jacques Derrida nació en el año 1930 en El-Biar, Argelia, en el seno de una familia sefardí. En 1952 fue aceptado en la École Normale Supérieure (ENS) y se instaló en París. Allí empezó su carrera académica, que transcurriría entre Francia y los Estados Unidos. Pasó el curso 1956-1957 en Harvard, becado, donde empezó la traducción de El origen de la geometría de Husserl, lo cual inauguró su primer tema de investigación: el concepto de génesis de Husserl. En sus primeros años como investigador, Derrida dedicó tres textos a Husserl: ${ }^{37}$ Le problème de la genèse dans la philosophie de Husserl (1953-1954), ${ }^{38}$ la "Introduction» a L'origine de la géométrie de Husserl (1962) y La voix et le phénomène. Introduction au problème du signe dans la phénoménologie de Husserl (1967b).

Aunque Husserl pasaría pronto a un segundo plano, todo el proyecto filosófico de Derrida es incomprensible sin sus primerizas reflexiones alrededor del pensamiento de este autor. De hecho, cuando en 1990 se publicó Le problème..., escrito casi cuarenta años antes, Derrida elaboró una breve «advertencia» en la que reconoció la continuidad de sus reflexiones de entonces y su vigencia, aunque admitió que con el tiempo tuvo que renunciar a algunos de los conceptos que forjó allí (1990: vi-vii). El objeto de estudio de este texto de Derrida es el concepto de génesis de Husserl. Según Derrida, esta noción reúne dos significaciones incompatibles: la de origen y la de devenir. Es decir, por un

37 Más adelante, en el año 2000, volvió sobre Husserl en Le toucher. Jean-Luc Nancy (2000). También dedicó a Husserl una serie de contribuciones más breves, como «"Genèse et structure” et la phénoménologie» (1959), incluida más tarde en L'écriture et la différence (1967c).

38 Este texto fue escrito en 1953-1954 para obtener el Diploma de Estudios Superiores en la ENS bajo la dirección de De Gandillac. Permaneció inédito hasta 1990. 
lado, solo hay génesis si hay un origen absoluto, un instante que no es fruto de ningún instante precedente; en pocas palabras, una «creación». Sin embargo, por otro lado, la génesis únicamente puede tener lugar en el seno de una totalidad ontológica que comprenda esta génesis. ${ }^{39}$ Derrida señala, pues, que Husserl intenta conciliar la idea de un comienzo absoluto, por un lado, y la temporalidad, por el otro, y ve en este intento un mérito, pero, como veremos, considera que Husserl se quedó a medias.

Con esta postura, Husserl se introdujo en el debate en torno a la dialéctica entre génesis (o historia) y estructura (o idea). Intentó integrar la estructura en un proceso genético, es decir, mostrar que las estructuras ideales tienen una génesis, de modo que no puede existir ninguna estructura despojada de una génesis ni ninguna génesis que no conlleve o no sea, ya, una estructura. No pueden haber estructuras atemporales. Es decir, la génesis no puede salir de la nada.

Derrida analiza esta idea y muestra que, llevada al límite, significa que toda la génesis ya debe estar allí para producir la génesis, a saber, que lo producido por la génesis es requerido para que la génesis pueda tener lugar o, lo que es lo mismo, que la génesis contiene, de antemano, la posibilidad de que la génesis tenga lugar. ¿Cómo puede ser, pues, que lo que posibilita la experiencia sea una síntesis a priori? (1990: 9-12). Este es el eje alrededor del cual gira todo el análisis de Derrida:

Si une synthèse a priori est à la source et au fondement de tout jugement et de toute expérience possibles, ne sommes-nous pas renvoyés sur une dialectique indéfinie? Comment l'originarité d'un fondement peut-elle être une synthèse a priori? Comment tout peut-il commencer par une complication? Si toute genèse et toute synthèse renvoient à leur constitution par une synthèse $a$ priori, la synthèse a priori elle-même, quand elle s'apparaît dans une expérience constituante, trans-cendantale et prétendue originaire, n'a-t-elle pas toujours «déjà» pris sens, n'est-elle pas toujours, par définition, «déjà» constituée par une autre synthèse, et ainsi à l'infini? (Ibíd.: 12-13). ${ }^{40}$

39 Escribe:

Tout d'abord, la genèse, examinée naïvement et le plus formellement possible, réunit dans son concept deux significations contradictoires: celle d'origine et celle de devenir. D'une part, en effet, la genèse est naissance, surgissement absolu d'un instant ou d'une «instance» irréductible à l'instance précédente, création, radicalité, autonomie par rapport à autre chose que soi; bref, il n'est pas de genèse sans origine absolue [...].

Mais, dans le même moment, il n'est de genèse qu'au sein d'une totalité ontologique et temporelle qui la comprend; tout produit génétique est produit par autre chose que soi, porté par un passé, appelé, orienté par un futur. Il n'est et n'a sa signification qu'inscrit dans un contexte qui, d'une part, est le sien, c'est-àdire auquel il appartient et participe, avec lequel il est en continuité, qu'en un certain sens il implique et, à la limite, comporte, comprend, connaît, mais qui, d'autre part, le déborde et l'enveloppe de tous côtés. La genèse est aussi une inclussion, une immanence (1990: 7-8).

Traducción al castellano (Trad. de la A.):

De entrada, la génesis, examinada de manera naif y del modo más formal posible, reúne en su concepto dos significaciones contradictorias: la de origen y la de devenir. Por un lado, en efecto, la génesis es nacimiento, surgimiento absoluto de un instante o de una «instancia» irreductible a la instancia precedente, creación, radicalidad, autonomía en relación con otra cosa que ella misma; en pocas palabras, no hay génesis sin origen absoluto [...].

Pero, al mismo tiempo, solamente hay génesis en el seno de una totalidad ontológica y temporal que la comprende; todo producto genético es producido por otra cosa que sí mismo, llevado por un pasado, apelado, orientado hacia un futuro. Únicamente es y tiene su significación cuando está inscrito en un contexto que, por un lado, es el suyo, es decir, al cual pertenece y participa, con el cual está en continuidad, que en un cierto sentido implica y comporta, comprende, conoce; pero, por otro lado, lo sobrepasa y lo rodea por todos lados. La génesis es también una inclusión, una inmanencia.

40 Traducción al castellano (Trad. de la A.):

Si una síntesis a priori se halla en la fuente y en el fundamento de todo juicio y de toda experiencia posibles, ¿no somos reenviados en una dialéctica infinita? ¿Cómo puede, la originariedad del fundamento, ser una síntesis a priori? ¿Cómo puede empezar todo por una complicación? Si toda la génesis y toda la 
En pocas palabras: ¿cómo puede ser el «inicio» una síntesis a priori, es decir, un conocimiento que se requiera a sí mismo para generarse? A través de su análisis de las tesis de Husserl, se pregunta cuál es el momento originario de la génesis (¿anterior o posterior al sentido?) y responde que debe ser ambos a la vez:

Le moment originaire de la genèse qui constitue le sens devra être à la fois antérieur au sens pour que la constitution soit effective, et postérieur au sens pour que celui-ci nous soit donné dans une évidence a priori ou originaire (Ibíd.: 40). ${ }^{41}$

Así pues, Derrida postula la imposibilidad de toda determinación real de un comienzo (Ibid.: 6).

¿Cómo valora Derrida la contribución de Husserl? Derrida valora positivamente el hecho de que Husserl haya descubierto la síntesis a priori como fundamento de toda génesis y significación, es decir, haber tenido en cuenta el tiempo, el devenir y la historia en la producción de sentido y en la constitución del sujeto trascendental. Para Husserl, solamente hay ideales gracias a la repetición. Derrida hereda esta idea de repetición (Derrida; Bennington 1991: 85), pero se desmarca de cualquier idealidad. Esto es lo que Derrida valora negativamente de Husserl: que no haya sido consecuente con su descubrimiento (la síntesis a priori como fundamento de toda génesis, la repetición) y no haya reajustado su método (1990: 41). Dicho de otro modo, Derrida considera que Husserl cumple el papel de bisagra: le sirve como plataforma para distanciarse de autores anteriores (como Hegel), pero acaba cometiendo alguno de sus mismos errores. Es decir, a pesar de su descubrimiento, Husserl considera que es posible fundar, a partir de la experiencia, ciencias objetivas; cree que, a pesar del «retraso» de la conciencia respecto del mundo, la conciencia se inscribe en una teleología, cosa que permite que llegue a la presencia de sí. En pocas palabras, Husserl pretende restablecer una pureza original, como se ve en Ideas relativas a una fenomenología pura y a una filosofía fenomenológica (1913).

A partir de los años sesenta, Derrida dejó de centrarse en el estudio explícito del pensamiento de Husserl y empezó a forjar un proyecto propio. Puede considerarse que la publicación de L'écriture et la différence (1967), un libro compuesto por una serie de ensayos autónomos (algunos de ellos publicados con anterioridad), inaugura este llamado segundo periodo de la obra de Derrida, en el que refunde reflexiones procedentes de la lingüística y la ontología para criticar la metafísica occidental. En L'écriture et la différence, el lector advierte que el centro de interés de Derrida ha pasado de la epistemología — concretamente de la fenomenología de Husserl — a la ontología y la lingüística. Si bien la noción de signo había entrado en escena en 1962 a propósito de Husserl, lo cierto es que entonces Derrida sostenía, desde una perspectiva fenomenológica, que es imposible conocer las cosas, mientras que a partir de L'écriture et la différence dirá, cuestionando los postulados ontológicos tradicionales, que toda presencia es un signo. Sus tesis acerca de la epistemología pasan, pues, a aplicarse a la ontología. Y, con ello, difumina el límite entre la epistemología y la ontología.

Las obras más destacadas de este segundo periodo, comprendido entre 1967 y finales de los años setenta, son las siguientes: La voix et le phénomène. Introduction au problème

síntesis reenvían a su constitución por una síntesis a priori, la propia síntesis a priori, cuando se aparece en una experiencia constituyente, trascendental y supuestamente originaria, ¿no ha "ya» siempre adquirido sentido, no ha sido «ya» siempre constituida por otra síntesis y, así, al infinito?

${ }^{4}$ Traducción al castellano (Trad. de la A.): «El momento originario de la génesis que constituye el sentido tendrá que ser a la vez anterior al sentido para que la constitución sea efectiva, y posterior al sentido para que este nos sea dado en una evidencia a priori u originaria». 
du signe dans la phénomènologie de Husserl (1967b); De la grammatologie (1967a), que puede considerarse la matriz de su obra posterior; Marges de la philosophie (1972b), un conjunto de textos independientes; La dissémination (1972a), y Glas (1974). En ellas desarrolla tres ideas que examinaremos a continuación - la ausencia de un hors-texte $(a)$, la diseminación $(b)$, y la différance $(c)$ — y que nos servirán para luego sopesar la afinidad entre la concepción derrideana del lenguaje y la rabínica.

\section{a) «Il n'y a pas d'hors-texte»}

La cuestión central de De la grammatologie es la función de la escritura. ¿Es, la escritura, un mero medio, un simple instrumento al servicio del transporte de ideas? ¿O cumple una función más relevante? Derrida se decanta por esta segunda opción y muestra que la escritura, lejos de ser un simple soporte que viene después de las ideas y los conceptos, se halla antes: la escritura es anterior (conceptualmente) al lenguaje. En palabras del mismo Derrida: "l'écriture comprendrait le langage» ${ }^{42}$ (1967a: 16). Se trata de una idea que ya había aparecido en L'écriture... y en La voix..., pero es en De la grammatologie donde esta tesis se despliega con más amplitud y es sistematizada.

Derrida comparte con Saussure la idea de que el lenguaje escrito ha invadido el lugar del habla, pero sostiene que esto no es una novedad, sino que siempre ha sido así, es decir, que funciona estructuralmente así, y que no se debe corregir este hecho, sino simplemente tomar conciencia de él. Dicho de otro modo, Derrida, a diferencia de Saussure, no cree que en un momento dado de la historia el lenguaje escrito usurpase el lugar del habla, sino que "[l]a usurpation a toujours déjà commencé» ${ }^{43}$ (1967a: 55). La contaminación de la escritura es estructural.

Está claro que cuando Derrida critica duramente la concepción tradicional de la escritura y propone una forma alternativa que prioriza la escritura en detrimento del lenguaje tiene in mente una concepción de la escritura extraordinariamente amplia. Según él, la escritura no es únicamente una representación gráfica, sino que constituye la (pre) condición de posibilidad del lenguaje y del sentido; no solo del comprender (epistemología), sino también del ser (ontología). O, mejor dicho, la condición de posibilidad del sentido funciona como la escritura. Fijémonos en esta idea: por definición, la escritura siempre se refiere a otra cosa que no es ella misma. La aportación de Derrida es que en el lugar del inicio, es decir, de la apertura de la posibilidad, hay escritura, a saber, algo que, desde un punto de vista lógico, no puede ser lo primero. Esta es la aporía que, según la concepción derrideana de escritura, acecha todo inicio.

En consecuencia, la relación habitual entre el significante y el significado se ve alterada. Se tiende a creer que los significantes son inscripciones (físicas o sonoras) que se refieren a un significado no textual, es decir, que el significado es representado mediante significantes. Derrida, en cambio, advierte sobre la inexistencia del hors-texte. Solo hay significantes; no hay significados. Es decir, no existe ningún significado no textual. Ni un significado nos precede ni nos dirigimos hacia un significado. Afirma Derrida: «le texte ne commence jamais» ${ }^{44}$ (1972a: 371); siempre puede hallarse una escritura anterior (Ibíd.: 364). El lenguaje siempre está en exilio respecto de sí mismo: el medio para llegar y el punto de llegada nunca coinciden. El significado está diferido

42 Traducción al castellano (De la gramatología. México D. F.: Siglo XXI, 2003, 12): «la escritura comprendería el lenguaje».

43 Traducción al castellano (Ibíd., 49): «La usurpación ha existido desde un principio».

44 Traducción al castellano (La diseminación. Madrid: Fundamentos, 2007, 498): «El texto no empieza nunca». 
para siempre. Con esta idea, Derrida está aplicando sus reflexiones sobre el tiempo y la historicidad que desplegó a propósito de Husserl a la cuestión del sentido: el sentido está constituido por la historicidad. No hay sentido fuera de ella. ${ }^{45}$

\section{b) Diseminación}

La ausencia de un hors-texte no tiene solamente implicaciones lingüísticas, sino también, y especialmente, epistemológicas y ontológicas. Que el significante no consiga remitir a un significado conlleva la imposibilidad de clausurar cualquier sistema. La era del libro, escribe Derrida, ha acabado. La era actual es la de la escritura. Un libro acabado, cerrado, implicaría que la historia estaría prescrita, puesto que el libro es una teoría de la composición. ${ }^{46}$ En cambio, Derrida propone un inicio siempre reiniciado. Dado que el significado está diferido, el círculo no se cierra nunca; algo se escapa, siempre, a la completitud del sistema.

Este fenómeno obedece al hecho de que el sentido está diseminado. Derrida distingue claramente entre el fenómeno denominado polisemia y la diseminación. Una palabra polisémica tiene varios sentidos, mientras que una palabra que disemina no tiene ningún sentido concreto, definible, abarcable. Mientras que la polisemia «s'organise dans l'horizon implicite d'une résumption unitaire du sens, voire d'une dialectique [...] téléologique et totalisante qui doit permettre à un moment donné, si éloigné soit-il, de rassembler la totalité d'un texte dans la vérité de son sens» (1972c: 61), ${ }^{47}$ la diseminación «ne se laisse reconduire ni à un présent d'origine simple [...] ni à une présence eschatologique» (Ibíd.: 62). ${ }^{48}$ Según Derrida, las palabras «diseminan» sentido, pero resulta imposible «recoger» este sentido, abarcarlo. De ahí la limitación que Derrida detecta en la hermenéutica. Dice Derrida: "le quasi "sens" de la dissémination, c'est l'impossible retour à l'unité rejointe» (1972a: 299). ${ }^{49}$ Además, no hay una primera inseminación. La primera inseminación "ya» es diseminación (Ibíd.: 338).

\section{c) Différance}

La diseminación y la consecuente ontología (o anti-ontología o a-ontología) que esta perfila nos sitúan delante de una situación de difícil resolución: suprime el significado, pero, sin embargo, no desemboca en la homogeneidad de todos los significantes. Derrida no habla de la ausencia de sentido, sino, más bien, de la inmanencia del sentido.

45 Para una lúcida reflexión sobre la relación entre historicidad y sentido en Derrida, véase Hodge (2007), especialmente la página 81 y siguientes.

${ }_{46}$ En la era del libro, "[l]'histoire elle-même est prescrite. Son développement, ses irruptions, ses discontinuités mêmes ne doivent pas déconcerter ce volume musical, cette encyclopédie qui est aussi une "base générale" ou théorie de la composition» (1972a: 59). Traducción al castellano (La diseminación. Madrid: Fundamentos, 2007, 79): «La historia misma es prescrita. Su desarrollo, sus irrupciones, sus discontinuidades mismas no deben desconcertar a su volumen musical, a esa enciclopedia que es también una "base general o teoría de la composición" ».

47 Traducción al castellano (Posiciones. Valencia: Pre-textos, 1977, 59-60): «se organiza en el horizonte implícito de una reasunción unitaria del sentido, o sea de una dialéctica [...] teleológica y totalizante que debe permitir en un momento dado, por alejado que esté, reunir la totalidad de un texto en la verdad de su sentido».

${ }_{48}$ Traducción al castellano (Ibíd., 60): «no se deja llevar ni a un presente de origen simple [...] ni a una presencia escatológica».

${ }_{49}$ Traducción al castellano (La diseminación. Madrid: Fundamentos, 2007, 401): "el casi "sentido" de la diseminación es el imposible regreso a la unidad alcanzada». 
Los significantes son diferentes, cada uno «dice» algo distinto. De hecho, lo que caracteriza el modelo derrideano no es la unidad, la identidad ni la mismidad, sino la diferencia que nunca puede resolverse o sintetizarse en ninguna unidad, identidad ni mismidad. ¿Cuál es, pues, el motor que genera o produce estas diferencias no sintetizables? Tradicionalmente, se ha considerado que el motor de las diferencias tenía que ser un punto simple, pleno, indivisible. Como hemos visto, en cambio, Derrida ha considerado que el lugar tradicionalmente asignado a lo indivisible y simple tenía que contener algo múltiple, divisible y dividido, una ruptura o una falta. Una diferencia. Y que, por lo tanto, ya no podía mantener el nombre de origen ni de fundamento.

Derrida la bautizó con el nombre de différance. En la obra de Derrida, este término aparece por primera vez en 1965, en un ensayo sobre Artaud. ${ }^{50}$ Sin embargo, Derrida fue desplegando este término en otras obras (De la grammatologie, L'écriture..., La voix..., etc.) y fue en una conferencia de $1968^{51}$ donde hizo el análisis más minucioso de este.

Derrida explica que el neologismo différance procede del verbo diferir, que tiene dos acepciones, una con connotaciones temporales y otra con connotaciones espaciales. En el sentido temporal del término, diferir significa «aplazar», "dejar para más tarde» (1972b: 8). En su sentido espacial, diferir significa "no ser idéntico a otro», "ser diferenciable» (Ibíd.: 8). Añade que, para entender este término, también debe tenerse en cuenta su terminación en -ance. En francés, este tipo de terminación tiene una connotación tanto activa como pasiva, es decir, los términos acabados en -ance indican, a la vez, que "promueven» una acción (connotación activa) y que «reciben» una acción (connotación pasiva). Si se aplica esta doble connotación a la différance, hay que definir la différance no únicamente como lo que hace diferir las diferencias (connotación activa), sino también como lo que ya ha sido diferido (connotación pasiva). La différance imprime la diferencia y, a su vez, la recibe. En De la grammatologie ya lo había intuido: "La différance est donc la formation de la forme. Mais elle est d'autre part l'être-imprimé de l'empreinte» (1967a: 92).52

Así pues, la différance constituye la raíz de las diferencias y de las oposiciones y, a su vez, ya está diferida. Está en el lugar del significado último y, al aplicársele la doble connotación de -ance, se obtiene el siguiente resultado:

- El significado último está diferido para siempre (connotación pasiva).

- El significado último es lo que hace diferir las diferencias (connotación activa).

La différance, pues, diferida, difiere; indefinible, permite la definición (pero una definición nunca concluida); innombrable, permite nombrar. Es decir, el significado último no puede alcanzarse (no existe, en última instancia), pero, a su vez, posibilita el sentido. Así pues, no hay una idealidad a priori, sino que es la repetición o, mejor dicho, la iterabilidad, la que produce (algo parecido a) la idealidad. Señala hacia la imposibilidad del origen simple y hacia la necesidad de un suplemento originario: la «différance» requiere de las diferencias cuya condición de posibilidad es la «différance».

El estudio de la concepción rabínica del texto y del lenguaje pone de manifiesto que, en efecto, la concepción judía del texto y la derrideana guardan un asombroso parecido. El parentesco entre el pensamiento de Derrida y la tradición rabínica es innegable. A

50 «La parole soufflée», en Tel Quel, núm. 20, invierno de 1965. Posteriormente se incluyó en L'écriture... (1967c).

51 Se publicó simultáneamente en el Bulletin de la société française de philosophie, núm. 62, julioseptiembre de 1968, y en Théorie d'ensemble (París: Seuil). Posteriormente se incluyó en Marges (1972b).

52 Traducción al castellano (De la gramatología. México D. F.: Siglo XXI, 2003, 83): «La diferencia es, entonces, la formación de la forma. Pero es, por otra parte, el ser-impreso de la impronta». 
nuestro juicio, coinciden por lo menos en tres importantes puntos, que exponemos a continuación.

De entrada, la idea de una ausencia de hors-texte puede leerse como equivalente a la idea rabínica de que la realidad es eminentemente lingüística, de modo que solo existen comentarios, es decir, significantes, y no realidades extratextuales o significados. Así, Derrida, al aplicar a la lingüística occidental contemporánea las conclusiones de su análisis de los postulados de Husserl sobre la imposibilidad de concebir una estructura carente de génesis (y viceversa), se habría acercado a la concepción rabínica del lenguaje. Es cierto que también Bloom y otros teóricos literarios versan sobre la imposibilidad de dar por concluida la interpretación del texto. Pero es en Derrida donde esta idea se plantea explícitamente como ausencia de hors-texte. Incluso se ha llegado a afirmar que la idea de «il n'y a pas de hors-texte» procede directamente del judaísmo, concretamente del texto de un cabalista italiano de principios del siglo XIv, Menahem Recanati. Esta es la hipótesis de Moshe Idel (2003). Menahem Recanati, explica Idel, afirmaba la identidad entre Dios, la Torá y la totalidad de las ciencias. A partir de esta idea deducía que no hay nada fuera de la Torá y que, en la Torá, no hay nada que no esté, de antemano, en Dios. El texto de este cabalista italiano, advierte Idel, no fue traducido al latín, pero Gershom Scholem hizo referencia a él en un artículo publicado en 1955-1956. Derrida conoce este artículo, subraya Idel, puesto que lo cita en La dissémination (1972a). Según Idel, Derrida, al afirmar que "no hay nada fuera del texto», únicamente habría sustituido «Torá» por «texto». Según esta hipótesis de Idel, el paralelismo entre la concepción judía del texto y la derrideana no es fortuito. ${ }^{53}$

Ahora bien, hay que señalar que la identificación entre Dios y la Torá no es marginal en el judaísmo, y que la influencia de las categorías judías en el pensamiento derrideano no puede explicarse de una manera tan simple, puesto que pueden haber llegado a Derrida por múltiples canales. A nuestro juicio, más que por un influjo directo parece más verosímil que la impronta judía llegase a Derrida a través de los filósofos idealistas alemanes - Habermas (1961) 54 $^{5}$ analiza la influencia que la Cábala ejerció en algunos de ellos- - y a través de Heidegger, para quién, según Zarader (1990), el legado teórico judío funciona como una «impensada» condición de posibilidad ${ }^{55}$ de su propio pensamiento.

53 Idel ya había estudiado la deuda de Derrida con otros cabalistas. En «Infinities of Torah in Kabbalah» (1986) había afirmado: "vale la pena señalar que Derrida ha combinado la visión de la lógica de Abulafia con la definición del papel de la poesía propuesta por Stéphane Mallarmé» (1986: 149). (Trad. de la A.).

54 El texto de Habermas «The German Idealism of Jewish Philosophers» (1961), en el cual sostiene que el legado de la Cábala fue absorbido por el idealismo alemán, proporciona interesantes pistas para estudiar cómo pueden haber llegado una serie de categorías judías al pensamiento de Derrida. Según Habermas, una serie de autores idealistas se adhirieron, a pesar de no ser conscientes de ello, a una serie de ideas sobre el mundo y el lenguaje procedentes de la Cábala. Habermas arguye que la raíz, o al menos una de las raíces, de este fenómeno se encuentra en un discípulo de Böhme, Johann Jacob Spaeth, que, «sobrepasado por la consonancia de esta doctrina con la teosofía de Isaac Luria, se volvió hacia el judaísmo» (Habermas 1961: 38). (Trad. de la A.).

${ }_{55}$ Sin duda, el pensamiento judío ha influido claramente en el pensamiento derrideano. Sin embargo, es importante subrayar que una parte importante de esta influencia puede haber llegado a través de Heidegger, a pesar de la aparente inverosimilitud de esta hipótesis. Marlène Zarader (1990) intenta mostrar que en el pensamiento de Heidegger está presente, «en la forma de lo impensado», un cierto pensamiento hebraico. Lo impensado no se opone a lo pensado, explica, sino que es su núcleo o, podríamos decir, su condición de posibilidad: «Lejos de ser el otro de lo pensado, su exterior, lo impensado constituye su corazón [...]. Mi cuestión es, pues, la siguiente: ¿podemos encontrar en Heidegger huellas de una herencia que no reconocía, una herencia que funcionaría, pues, como lo impensado de su texto?» (Zarader 1990: 9). (Trad. de la A.). 
Sin embargo, dado que el objetivo de nuestro trabajo no es genealógico, baste por el momento afirmar el parecido conceptual entre la ausencia de un hors-texte y el carácter omniabarcante de la Torá.

Existe una segunda similitud entre la tradición rabínica y el pensamiento de Derrida, que es una consecuencia lógica de la que acabamos de exponer: ambos comparten la idea de que no puede proporcionarse una interpretación cerrada y definitiva del texto. Como pone de manifiesto la interpretación que Derrida hace del cuento de Allan Poe sobre la carta robada ${ }^{56}-\mathrm{y}$, especialmente, de la lectura lacaniana ${ }^{57}$ de dicho cuento- la carta nunca llega a su destinatario. El significante nunca logra hacer presente el significado. Este siempre se escapa; está diferido para siempre. El motivo: la diseminación. Sin duda se trata de una idea que no es para nada extraña a la tradición rabínica; por ejemplo, a la interpretación rabínica del salmo 62 y del versículo de Jeremías al que nos hemos referido más arriba. Es cierto que la misma idea desempeña un papel importante en las propuestas de muchos otros teóricos literarios; por ejemplo, en Bloom, como hemos visto. Sin embargo, Bloom plantea el texto como susceptible de un proceso de interpretación que va in crescendo, de modo que la interpretación se acerca progresivamente a la «completitud». Derrida, en cambio, es más cercano a la visión rabínica del texto porque considera que el texto puede interpretarse de maneras distintas, de modo que incluso se pueden dar ideas difícilmente reconciliables.

Existe aún otro tercer evidente paralelismo, que, a nuestro juicio, constituye de hecho la raíz de los dos parecidos expuestos. Si la concepción derrideana del lenguaje se asemeja más a la rabínica que la de otros teóricos literarios es porque, en última instancia, tanto en el pensamiento de Derrida como en la concepción rabínica del texto subyace una determinada manera de concebir la ontología que resulta extraordinariamente cercana -y que los teóricos literarios contemporáneos o bien no comparten, o bien no tematizan de una forma tan exhaustiva.

Este es un tercer punto en el que la tradición rabínica y la concepción derrideana del lenguaje se asemejan: para ambos, el motivo último por el que no se puede alcanzar una interpretación concluyente de un texto es que lo que ocupa el lugar tradicionalmente otorgado al concepto de «origen» —o al de arché, o al significado transcendental— está roto, escindido, porque es de naturaleza textual. Dicho de otro modo, en su desmarcarse de Husserl —así como en su criticar el concepto de arché de la mayor parte de la filosofía occidental - no es que Derrida proponga algo nuevo ni se deshaga del concepto de génesis, del concepto de origen, o del concepto de Dios. Simplemente intenta mostrar que el concepto occidental de arché —y el de Dios- es textual, está inscrito en el texto, aunque los pensadores anteriores no se percataran de ello. Según Derrida, es por eso que ya no

Según Zarader, Heidegger repiensa la cuestión griega con categorías judías. La idea principal de Zarader es que Heidegger y el pensamiento judío comparten la idea de una llamada original: el «Escucha, oh Israel» (Dt 6, 4) tiene su análogo en la llamada heideggeriana que abre, permite, la posibilidad del pensar. Para ambos, en el origen no hay plenitud, sino llamada, es decir, apertura; y, para ambos, el pensamiento y el texto no concluyen, no llegan jamás al significado último. He aquí, añadimos nosotros, el paralelismo con la différance. Evidentemente, la hipótesis de una posible influencia judía en Derrida vehiculada a través de Heidegger debería ser estudiada con mucha más profundidad.

56 En La carta robada (1844), la reina está leyendo una carta cuando, repentinamente, irrumpe el rey en la habitación y ella, para evitar ser descubierta, pone la carta boca abajo. El ministro advierte su gesto y, a escondidas, coge la carta, pero no la lee para no despertar la curiosidad del rey. La reina, dispuesta a recuperar su carta sin llamar la atención del rey, ordena que se busque la carta por las dependencias del ministro. La búsqueda de la carta, ausente, vertebra la historia. La carta pasa por distintas manos, pero su significado permanece una incógnita. Derrida tematiza este texto en «The Purveyor of Truth» (1975).

57 Seminario de 1955. 
puede denominarse fundamento y que hace falta acuñar un nuevo término (él propone différance). En otras palabras: decir que el concepto de origen es de naturaleza textual equivale a decir que no se basta a sí mismo para generarse, sino que parece requerir de algo anterior, del mismo modo que los textos no constituyen un origen absoluto, sino que nacen dentro de un marco. En definitiva, el concepto de origen, en la medida en que es textual, es un concepto contradictorio porque no puede generarse a sí mismo (en ese punto es preciso tener en cuenta que nos referimos al concepto de Dios, no a Dios).

Derrida intenta sacar a la luz, pues, las contradicciones en las que incurren pensadores anteriores como consecuencia de no haberse percatado del carácter contradictorio del concepto de origen. En ese gesto, Derrida acaba planteando una noción de fundamento y de origen extraordinariamente parecida a la rabínica, puesto que tampoco para el judaísmo se puede dar con una definición del concepto de origen que no remita a otras palabras que, a su vez, remiten a otras, todas ellas susceptibles de diferentes interpretaciones.

La lista de elementos compartidos por la propuesta derrideana y la rabínica podría prolongarse, pero simplemente se trataría de consecuencias lógicas de las tres afinidades expuestas. Queremos, pues, ir todavía un poco más allá en el análisis de estas tres similitudes. A nuestro juicio, las tres similitudes que hemos señalado derivan de la especial atención que tanto Derrida como el judaísmo otorgan a los particulares, oponiéndose a la lógica de origen griego. En la filosofía griega —especialmente la platónica y la plotiniana que en ella se inspiró- adquirió un papel fundamental la idea de que entre los particulares y los universales existe una relación de correspondencia. En primer lugar, los particulares obedecen a las normas impuestas por los universales, de modo que los particulares carecen de margen de maniobra propio. En segundo lugar, los particulares son ontológicamente inferiores a los universales porque están subordinados a ellos. Ambas ideas pasaron a formar parte de los presupuestos de la filosofía occidental antigua y medieval —a pesar de algunas voces disidentes, minoritarias, como Guillermo de Ockham. ${ }^{58}$

En cambio, en los textos de corte rabínico, el particular solía tener un estatus superior. No se trataba de un capricho teórico, sino de un fruto lógico del concepto judío de creación del mundo y, en última instancia, del concepto judío de Dios: lo que lo sostiene todo es la constante supervisión de Dios sobre cada cosa — sobre cada particular-, de modo que el particular no sigue un curso lógico y predecible establecido por el universal. De este modo, el hecho de que Iahvé sea un Dios personal y tenga voluntad tiene una serie de implicaciones - no solo en el ámbito de la cosmogonía y la ontología, sino también en el de la epistemología - que lo hacen incompatible con la concepción griega del mundo, ${ }^{59}$ porque amenaza las leyes naturales de los filósofos y físicos griegos, regidas por una lógica supuestamente impecable que subsume, ata y determina la conducta de los particulares.

La obra derrideana no incluye en absoluto a un Dios omnipotente que rompe el curso normal de los acontecimientos, ${ }^{60}$ pero sí que incluye esta dislocación entre los particulares — significantes_ y los universales — significados_, y la imposibilidad de

58 Véase Guillaume d'Ockham le singulier (1989), de Pierre Alféri.

59 Para una exploración rica y minuciosa de los problemas teóricos que conllevó para el judaísmo los intentos de incorporar la doctrina plotiniana, inspirada en Platón, véase «La confrontación entre el Dios bíblico y el Dios de Plotino en la antigua cábala» (Scholem: 1970).

60 De entrada, la vasta obra derrideana parece no solo excluir el concepto tradicional de Dios, sino también imposibilitarlo. Sin embargo, cuando Caputo empieza a leer, desde un cristianismo muy heterodoxo, la obra de Derrida, y a preguntarse si esta admite un Dios débil y vulnerable, Derrida admite que 
reducir los particulares a los comportamientos establecidos por los universales. Deudor del judaísmo —y del gesto de Kierkegaard contra Hegel-, Derrida reivindica los particulares, y esto está en el origen de las nociones que articulan su pensamiento: la différance, la ausencia de hors-texte, la dissémination. De hecho, en su reivindicación de los particulares, Derrida incluso hace estallar la posibilidad de distinguir netamente entre particulares y universales.

Ahora bien, queremos señalar que, a pesar del indiscutible paralelismo que presentan la noción derrideana del lenguaje y la rabínica, entre ellas existen una serie de diferencias cruciales. Un número relevante de autores se han esforzado por mostrar que la propuesta teórica de Derrida encajaba con la judía. ${ }^{61}$ Sin embargo, en nuestra opinión, estos teóricos parecen pasar por alto que Derrida se desmarca de la tradición rabínica en una serie de importantes puntos.

En primer lugar, podría afirmarse que, en realidad, la diferencia entre la concepción judía del texto y la derrideana no es conceptual, sino de creencia: la lógica, a saber, la sucesión de conceptos vinculados mediante nexos de causalidad, hace abocar ambas concepciones del texto a lo mismo - la ausencia de un hors-texte-, pero la primera, la judía, hace un salto y «cree» en Dios, mientras que la segunda, la derrideana, simplemente no se entromete en esta cuestión. Se ha dicho que el pensamiento de Derrida es el propio de un «ateo radical» (Hägglund 2012). Sin embargo, habría que tener en cuenta que resulta imposible calificar el pensamiento de Derrida en este aspecto. Derrida habla sobre la imposibilidad de incluir el concepto Dios en el discurso racional sin generar contradicciones lógicas, pero no de la existencia o inexistencia de Dios. Algunos teóricos no han comprendido esta idea porque han interpretado erróneamente la idea derrideana de la ausencia de hors-texte. Es importante tener en cuenta que Derrida sostiene que no existen conceptos exteriores al texto, pero no que no existan cosas fuera del texto. Es decir, que no haya un hors-texte equivale a decir que no hay un metalenguaje, a saber, un lenguaje que permita hablar del lenguaje, pero no equivale a la suspensión de la referencia. ${ }^{62}$ Esta idea se comprende mejor si se tiene en cuenta una corrección que Émile Benveniste (1966) efectuó a las tesis sobre el signo de Saussure. Según Benveniste, por significado hay que entender un "concepto», no una "cosa». Saussure, sostiene Benveniste, se confunde y a veces utiliza el término significado como si fuera un sinónimo de $\operatorname{cosa} .^{63} \mathrm{Si}$ tenemos in mente la acepción benvenistiana de significado, resulta imposible

de entrada no le parece contradictorio con su propuesta. Véase la entrevista que Caputo hizo a Jacques Derrida, titulada «Epoché and Faith. An Interview with Jacques Derrida» (Sherwood; Hart 2005).

61 Véase la nota 6.

62 En este sentido, escribe Derrida: «Il faut éviter en effet que la critique indispensable d'un certain rapport naïf au signifié ou au référend, au sens ou à la chose, ne se fixe en une suspension, voire une suppression pure et simple du sens et de la référence» (1972c: 90). Traducción al castellano (Posiciones. Valencia: Pre-textos, 1977, 87): «Hay que evitar, en efecto, que la crítica indispensable de cierta ingenua relación al significado o al referente, al sentido o a la cosa, no se fije en una suspensión, hasta una supresión pura y simple del sentido y la referencia».

${ }_{63}$ Benveniste (1966) saca a colación esta confusión para mostrar que Saussure se equivoca al decir que la relación entre el significante y el significado es arbitraria. Según Benveniste, la relación entre el significante y el significado no es arbitraria, sino necesaria. Lo que es arbitrario es la relación entre el signo y la cosa. Saussure, sostiene Benveniste, se confunde, porque a veces, sin percatarse de ello, emplea el término significado cuando en realidad quiere referirse a cosa. En palabras del propio Benveniste:

«Uno de los componentes del signo, la imagen acústica, constituye su significante; otro, el concepto, es el significado. Entre el significante y el significado el nexo no es arbitrario; al contrario, es necesario. El concepto («significado») boeuf es por fuerza idéntico en mi conciencia al conjunto fónico («significante») böf. ¿Cómo iba a ser de otra manera? Los dos juntos han sido impresos en mi espíritu; juntos se evocan en toda circunstancia [...] Lo que es arbitrario es que tal signo, y no tal otro, sea aplicado a tal elemento de 
leer erróneamente el postulado derrideano de la ausencia de hors-texte: que no haya un hors-texte no quiere decir que no hay «cosas» fuera del texto, sino que no hay «conceptos» fuera del texto.

De entrada, pues, existe una diferencia entre la concepción rabínica del texto y la derrideana. La misma lógica subyace bajo ambas, pero la primera hace un «salto» y cree en Dios, mientras que la segunda no tematiza esta cuestión; la primera está al servicio de la comprensión de la palabra divina, fue diseñada para ello, mientras que la segunda surge en contacto con el pensamiento de Husserl y para su exploración.

Ahora bien, consideramos que antes de esta decisión entre «saltar» o no, existen otras dos diferencias entre la concepción judía del texto y la derrideana; estas dos, sí, conceptuales.

Una segunda diferencia entre la concepción derrideana del lenguaje y la rabínica tiene que ver con las distintas maneras en las que desde ambos enfoques se respondería la siguiente pregunta: ¿cuál es la causa de la inaprehensibilidad del significado? En otras palabras, ¿por qué no existe un hors-texte? El motivo que Derrida atribuye a la inaprehensibilidad del significado no radica en la inefabilidad de la realidad externa, sino que se encuentra en el funcionamiento mismo del lenguaje. Es decir, que el significado esté diferido no significa que una serie de elementos de la realidad se resistan a ser simbolizados; este fenómeno obedece, más bien, al hecho de que el lenguaje excluye la posibilidad de comprenderse a sí mismo. ${ }^{64}$ En palabras de Sonia Arribas:

El lenguaje está dislocado porque está compuesto por una función semiótica -mediante la cual presuponemos conceptos-y una función semántica —-mediante la cual aludimos a algo-, y debido al hecho de que entre estas dos funciones tiene lugar un intercambio (o dislocación) sobre el que no podemos hablar — sobre el que sólo podemos tener una «intuición»- Esta dislocación es la condición de posibilidad del lenguaje (Arribas 2003: 5-6). (Trad. de la A.).

En cambio, para la tradición rabínica, el motivo por el que la realidad no puede abarcarse conceptualmente de manera concluyente no es fundamentalmente lingüístico, sino teológico: el elemento último de la realidad —Dios- es y tiene que ser inefable. Esto tiene implicaciones lingüísticas, obviamente, pero son la consecuencia, y no la causa, de la inefabilidad divina y de la inefabilidad de la realidad.

Esta idea está estrechamente emparentada con el tercer motivo por el que, a nuestro juicio, la concepción derrideana del lenguaje se desmarca de la rabínica. Según la tradición judía, Dios no puede representarse o, lo que es lo mismo, solamente puede representarse como ausencia. Si aplicamos las reflexiones teológicas de Jean-Luc Marion

la realidad, y no a tal otro. [...] No es entre significante y significado donde la relación al mismo tiempo se modifica y permanece inmutable, sino entre signo y objeto; es en otros términos, la motivación objetiva de la designación, sometida, como tal, a la acción de diversos factores históricos. Lo que Saussure demuestra sigue siendo cierto, pero acerca de la significación, no del signo» (1966: 51-53).

${ }^{64}$ Zizek lo explica de la siguiente manera:

No es que necesitemos palabras para designar los objetos, para simbolizar la realidad y que luego nos encontremos con un excedente, con que hay cierto exceso de realidad, un núcleo traumático que se resiste a la simbolización. Esta es una explicación oscurantista del Núcleo innombrable de la Realidad más elevada que supuestamente permanece fuera del alcance del lenguaje y, por lo tanto, debe rechazarse por completo, no para defender ingenuamente la creencia de que todo puede ser nombrado, que nuestra razón puede captarlo todo, sino para dejar sentado el hecho de que lo Innombrable es un efecto del lenguaje. Tenemos la realidad ante nuestros ojos mucho antes de contar con el lenguaje, y lo que el lenguaje hace, en su gesto fundamental, es, como dice Lacan, exactamente lo contrario de designar la realidad: el lenguaje cava un agujero en la realidad [...]. Cuando te veo, simplemente te veo, pero sólo cuando te nombro puedo indicar el abismo que hay en ti detrás de lo que yo veo (2003: 98). 
sobre lo que él denomina «metafísica de la ausencia» ${ }^{65}$ al pensamiento rabínico podemos afirmar que para la tradición judía Dios constituye un «fenómeno saturado» que, en tanto que tal, excede todo concepto. Para Marion hay una serie de "fenómenos saturados», como es el caso de ciertas experiencias muy intensas - como el nacimiento, la muerte, el amor, la traición y el propio Dios- que no pueden ser contenidas en ninguna intención, significante o concepto. Dios es uno de ellos: "se da», pero no puede ser captado mediante ninguna intuición, idea, concepto o significante. En palabras del propio Marion, «ya no parece posible ni predicar ni nombrar [...] no porque falte la intuición [...], sino porque el exceso de intuición supera, excede, en una palabra, satura, la medida de cada concepto» (1999: 309). (Trad. de la A.) Es decir, la imposibilidad de aprehender algo no es consecuencia de que el fenómeno se dé insuficientemente, sino, por el contrario, de que su «donación» es tan excesiva que no puede ser contenido en ningún concepto.

John D. Caputo (2003) sostiene que, para Derrida, esta inadecuación entre la intención (el concepto) y aquello a lo que alude no es fruto de un exceso del significado sobre el significante, sino precisamente de lo contrario: del hecho de que el significante excede el significado. Si aplicamos su razonamiento a la cuestión que nos ocupa, esto nos permite señalar otra diferencia entre la concepción derrideana del lenguaje y la rabínica. Dicha diferencia refuerza la segunda diferencia entre ambas que hemos señalado, que hemos formulado ayudándonos de la manera cómo Sonia Arribas explica la dislocación de lenguaje: el motivo por el que, según Derrida, jamás se alcanza un hors-texte no tiene que ver con la inefabilidad de la realidad externa, sino con una fisura interna al lenguaje.

\section{CONCLuSIÓN}

En resumen, la noción derrideana de lenguaje se distingue de la rabínica por lo menos en tres puntos: en primer lugar, la noción rabínica respalda una creencia, mientras que la derrideana en ningún momento escapa a la lógica; en segundo lugar, según el judaísmo, la realidad última es inalcanzable porque Dios es inefable por naturaleza, mientras que el motivo que Derrida arguye para descartar la posibilidad de alcanzar la realidad última tiene que ver exclusivamente con una fisura interior al lenguaje; en tercer lugar, para el judaísmo — como para la mayor parte de los enfoques teológicos sobre el lenguaje - la imposibilidad de alcanzar un significado es una cuestión epistemológica - la tradición judía quiere evitar a toda costa el ídolo - mientras que para Derrida, en cambio, tiene implicaciones ontológicas (el significante excede al significado).

Ahora bien, para ser más precisos habría que desmarcarnos ligeramente de Caputo y decir que no se trata propiamente de un exceso del significante - o del lenguaje — sobre el significado - o realidad-, sino de una relación aporética entre las dos partes de este binomio. Desarrollémoslo: si bien es cierto que la concepción derrideana del lenguaje socava el concepto de significado, de modo que los significantes salen reforzados,

65 Véase el texto de Marion "In the Name: How to Avoid Speaking of "negative theology" (1999) para una caracterización de la «metafísica de la ausencia». Según Marion, la teología mística no tiene porqué inscribirse en el horizonte del Ser y, por ende, ser ontoteológica (Marion 1999: 299); no tiene, pues, porqué ser una «metafísica de la presencia». En sus propias palabras:

La denominación, pues, no acaba en una «metafísica de la presencia» que no se llama a sí misma de este modo. Más bien acaba en una teología de la ausencia [...]. Por teología de la ausencia, pues, no nos referimos a la no-presencia de Dios, sino al hecho de que el nombre de Dios se da, el nombre que da Dios, que se da como Dios [...] sirve para proteger a Dios de la presencia (Ibid., 306). (Trad. de la A.). 
Derrida no propone exactamente que los significantes sean excesivos respecto de los significados. No podemos estar de acuerdo con Caputo en ese punto: más bien habría que decir que entre significantes y significados existe una relación aporética.

En la concepción del lenguaje propia de la tradición occidental, existe una correspondencia entre los significantes y los significados: los primeros se refieren a los segundos; aunque a veces sea por medio de otros significantes, al final de la cadena de la significación se halla un significado. Este significado, a su vez, es la condición de posibilidad del significante, a saber, lo que abre o inaugura la posibilidad teórica de existir del significante. Como hemos visto, Derrida, en cambio, revela que los significantes remiten a otros significantes, y estos a su vez, a otros, de modo que nunca se da con ningún significado. En última instancia, pues, únicamente existen significantes. Ahora bien, la noción derrideana de significante asume y ejerce una parte importante del papel tradicionalmente asignado al significado. Él solo es responsable de que el proceso de significación funcione. En consecuencia, resulta imposible distinguir con nitidez los significantes de los significados, es decir, la diferencia entre ambos estalla porque resulta imposible determinar si los significantes tienen más de significado (tradicional, clásico) o de significante. Durante el intento de determinarlo, de repente el significante se convierte en significado y este, a su vez, en significante, como si se tratase de un guante de plástico del que queremos ver la parte interior y que, de golpe, se vuelve del revés.

El motivo: uno es la condición de posibilidad del otro. El significante saca su razón de ser de la posibilidad de que existan significados, pero los significados son meras posibilidades que abren el proceso de significación y que, en tanto que meras posibilidades, están condenados a nunca adquirir existencia; en tanto que meras posibilidades, siempre se escapan. Esta posibilidad es, a su vez, consecuencia del hecho de que hay significantes. En pocas palabras: los significantes requieren y nos reenvían a los significados, y estos a los primeros, sumiéndonos en un movimiento interminable de naturaleza aporética. Los significantes son la condición de posibilidad de los significados, y estos, a su vez, de los significantes.

Este es un problema ausente en los textos rabínicos y en los cabalísticos: para dichos textos, el hecho de que los significantes nunca alcancen plenamente un significado, o nunca logren describir unívocamente la realidad, no es debido a una relación aporética entre los significantes y los significados. En el caso de la concepción rabínica del lenguaje, Dios excede a los significantes porque constituye, como hemos visto, lo que Marion llama un «fenómeno saturado».

Ahora bien, llegados a este punto es importante que nos planteemos una cuestión que hasta el momento no hemos resuelto: Dios es inefable y, en consecuencia, constituye un fenómeno saturado que, en tanto que tal, no puede ser abarcado por ningún significante. Pero: ¿por qué según la literatura rabínica, el mundo (y las cosas del mundo) tampoco puede ser abarcado por los significantes?

Para dar respuesta a esa cuestión es preciso tener en cuenta que mientras Marion - y la teología cristiana- considera que solamente existen algunos fenómenos inefables o saturados, de modo que solo algunos significados resultan inalcanzables o diferidos, para el pensamiento judío la cosa es muy distinta debido a su tendencia panteísta, que se halla claramente en el pensamiento rabínico (en la unidad entre el texto, Dios y la realidad que hemos expuesto en la primera sección) y en la Cábala (Dios emana a través de las sefirot, esparciéndose por todo el mundo). ${ }^{66}$ Para el pensamiento rabínico y para

66 Como hemos explicado en la nota 32, hubo cabalistas que consideraron que las sefirot no solo eran instrumentos al servicio de la manifestación de la divinidad, sino que ya participaban de la divinidad. 
la Cábala, toda la realidad está imbuida de la divinidad, que por definición es inefable. En consecuencia, podríamos afirmar que todos los fenómenos pueden considerarse «saturados». Es por eso, pues, que todos los significados están necesariamente diferidos. Es importante señalar que no estamos afirmando que para el judaísmo toda la realidad sea Dios. Pero sí es verdad que un cierto panteísmo, a menudo más débil, se halla en la base de su concepción del mundo. Así pues, la realidad no puede ser abarcada conceptualmente de manera completa porque tiene algo de divina o, si se prefiere una versión más alejada del panteísmo — que también se halla en la vasta y diversa tradición judía-, porque su último fundamento está en Dios, que es inefable.

En resumen, en la raíz de la imposibilidad rabínica de interpretar completamente un texto o de captar la totalidad de cualquier aspecto de la realidad se halla la tendencia panteísta propia del judaísmo. En la différance derrideana, en cambio, subyace una aporía teórica totalmente ajena al judaísmo, aunque los efectos de ambos fenómenos — del panteísmo, por un lado, y de la différance, por otro- guarden un estrecho parentesco. A nuestro juicio, esta es la raíz de las múltiples diferencias que existen entre la noción derrideana del lenguaje y la rabínica.

\section{BiBLIOGRAFÍA CITADA*}

Alféri, P. (1989). Guillaume d'Ockham le singulier. París: Minuit, 1989.

ARIstóteles. Metafísica. Barcelona: Espasa Calpe, 2013.

Arribas, S. (2003). The Last Conceptual Revolution? The Place of Language in Political Philosophy. Tesis doctoral. Nancy Fraser (dir.). Graduate Faculty of Political and Social Science of the New School University.

Barthes, R. (1979). «From Work to Text». En: Josué V. HARARI (ed.). Textual Strategies. Nueva York, Ithaca: Cornell University Press, 73-81.

Bergo, B.; Cohen, J.; Zagury-orly, R. (eds.) (2007). Judeities. Questions for Jacques Derrida. Nueva York: Fordham University Press.

Beuchot, M. (1986). «Signo y lenguaje en San Agustín». En: Dianoia, núm. 32, p. 13-26.

Benveniste, É. (1966). Problemas de lingüística general I. México D. F.: Siglo XXI, 1991.

Bennington, G. (1991). Jacques Derrida. Madrid: Cátedra, 1994.

Bцоoм, H. (1973). La angustia de las influencias. Caracas: Monte Ávila, 1991.

- (1975a). A Map of Misreading. Nueva York: Oxford University Press.

- (1975b). La Cábala y la crítica. Caracas: Monte Ávila, 1992.

- (1979). «The Breaking of Form». En: Harold Bloom [et al.]. Deconstruction and Criticism. Nueva York: Seabury Press, 2004, p. 1-31.

- (1982). Los vasos rotos. México D. F.: FCE, 1986.

Caputo, J. D. (2003). «Derrida and Marion. Two Husserlian Revolutions». En: Jeffrey Bloechl (ed.) (2003). Religious Experience and the End of Metaphysics. Bloomington: Indiana University Press, p. 119-134.

Cixous, H. (2001). Portrait de Jacques Derrida en Jeune Saint Juif. París: Galilée.

DERRIDA, J. (1962). «Introduction». En: Edmund HusserL. L'origine de la géométrie. París: PUF, p. 3-171.

- (1967a). De la grammatologie. París: Minuit, 2006.

- (1967b). La voix et le phénomène. Introduction au problème du signe dans la phénoménologie de Husserl. París: PUF, 1993.

* En la bibliografía, hemos indicado entre paréntesis el año de la primera edición de los textos. A lo largo del trabajo, hemos utilizado exclusivamente esta fecha cuando hemos citado una obra; sin embargo, las páginas a las que nos referimos son las de la edición empleada (que cuando no coincide con la primera edición, el año de publicación aparece al final de la referencia bibliográfica).

No hemos indicado el año de la primera edición de las obras anteriores al siglo XVII. 
- (1967c). L'écriture et la différence. París: Seuil, 1979.

- (1972a). La dissémination. París: Seuil.

- (1972b). Marges de la philosophie. París: Minuit.

- (1972c). Positions. París: Minuit, 2007.

- (1974). Glas. París: Galilée.

- (1975). «The Purveyor of Truth». En: Yale French Studies, núm. 52: Graphesis: Perspectives in Literature and Philosophy, p. 31-113.

- (1986). Schibboleth. Pour Paul Celan. París: Galilée.

- (1990). Le problème de la genèse dans la philosophie de Husserl. París: PUF.

- (1991). Circonfession. París: Seuil.

- (1993). Spectres de Marx: l'état de la dette, le travail du deuil et la nouvelle Internationale. París: Galilée.

- (1996). "Foi et savoir. Les deux sources de la "religion" aux limites de la simple raison». En: Jacques Derrida; Gianni Vattimo (dirs.) (1996). La religion. París: Seuil, p. 9-86.

- (1997). Adieu à Emmanuel Lévinas. París: Galilée.

- (2000). Le toucher. Jean-Luc Nancy. París: Galilée.

- (2002). «Hostipitality». En: Gil ANIDJAR (ed.) (2002). Acts of Religion. Nueva York; Londres: Routledge, p. 356-420.

Drob, S. L. (1997). «The Sefirot: Kabbalistic Archetypes of Mind and Creation». En: Cross Currents, vol. 47, núm. 1 [en línea]. <www.crosscurrents.org/Drob.htm> [Consulta: 20 abril 2013].

- (2006). «Jacques Derrida and the Kabbalah». En: The New Kabbalah [en línea]. <www. newkabbalah.com/JDK.pdf> [Consulta: 20 abril 2013].

Dufourmantelle, A. (1997). De l'hospitalité. París: Calmann-Lévy.

Greenstein, M. (1986). «Derrida and the Diaspora». En: Response, vol. 15, núm. 2, p. 33-41.

Habermas, J. (1961). «The German Idealism of the Jewish Philosophers». Philosophical-Political Profiles. Cambridge: The MIT Press, 1983, p. 21-43.

HäGglund, M. (2012). «L'athéisme radical de Derrida». En: Les temps modernes, núm. 670 (juliooctubre), p. 287-305.

Handelman, S. A. (1982). The Slayers of Moses: The Emergence of Rabbinic Interpretation in Modern Literary Theory. Albany: State University of New York Press.

Hart, K.; Sherwood, Y. (2005). «Epoché and Faith: An Interview with Jacques Derrida». En: Sherwood, Y.; HaRt, K. (eds.) (2005). Derrida and Religion. Other Testaments. Nueva York; Londres: Routledge, p. 27-50.

Hartman, G. H.; Budick, S. (eds.) (1986). Midrash and Literature. New Haven; Londres: Yale University Press.

Hodge, J. (2007). Derrida on Time. Londres; Nueva York: Routledge.

HusserL, E. (1913). Ideas relativas a una fenomenología pura y a una filosofía fenomenológica. México D. F.: FCE, 1993.

Idel, M. (1986). «Infinities of Torah in Kabbalah». En: Hartman; Budick (1986), p. 141-157.

- (1992). Mesianismo y misticismo. Barcelona: Riopiedras, 1994.

- (2003). «Jacques Derrida and Kabbalistic Sources». En: Bergo; Cohen; Zagury-Orly (2007), p. 111-130.

MARION, J.-L. (1999). «In the Name: How to avoid speaking of "negative theology"». En: Jonathan Culler (ed.) (2003). Deconstruction. Critical Concepts in Literary and Cultural Studies. Nueva York; Londres: Routledge, 289-323.

Platón. Crátilo. México: UNAM, 2009.

Roitman, B. (1986). «Sacred Language and Open Text». En: Hartman; Budick (1986), p. 159-175.

Rosàs Tosas, M. (2008). «La desconstrucció derridiana i l'ètica: incompatibles?». En: Ars Brevis, núm. 14, p. 317-330.

San Agustín de Hipona. El maestro o sobre el lenguaje y otros textos, Trotta, 2003.

Scholem, Gershom (1941). Las grandes tendencias de la mística judía. Madrid: Siruela, 2006.

- (1970). «La confrontación entre el Dios bíblico y el Dios de Plotino en la antigua cábala». Conceptos básicos del judaísmo. Trotta: Madrid, 1998, p. 11-46.

- (1971). Le messianisme juif. Essais sur la spiritualité du judaïsme. París: Calmann-Lévy, 1974.

Sharon Ash, B. (1987). «Jewish Hermeneutics and Contemporary Theories of Textuality: Hartman, Bloom, and Derrida». En: Modern Philology, vol. 85, núm. 1, p. 65-80. 
Torralba, F. (2004). "No olvidéis la hospitalidad» (Heb 13,2). Una exploración teológica. Madrid: PPC.

Weber, E. (1994). Questioning Judaism. Stanford: Stanford University Press, 2004.

Wolfson, E. R. (2002). «Assaulting the Border: Kabbalistic Traces in the Margins of Derrida». En: Journal of the American Academy of Religion, vol. 70, núm. 3, p. 475-514.

Wolosky, S. (1998). An «Other» Negative Theology: On Derrida's «How to Avoid Speaking: Denials». En: Poetics Today, vol. 19, núm. 2, p. 261-280.

Zarader, M. (1990). The Unthought Debt. Heidegger and the Hebraic Heritage. Stanford: Stanford University Press, 2006.

Zizeк, S. (2003). El títere y el enano. El núcleo perverso del cristianismo. Buenos Aires: Paidós, 2006.

Full-time lecturer en el Department of Romance

Mar Rosàs Tosas Languages and Literature

mrosas@uchicago.edu

[Artículo aprobado para publicación en noviembre de 2013] 